\title{
Teaching medical ethics in other countries
}

\author{
Sir Gordon Wolstenholme Harveian Librarian, The Royal College of Physicians
}

\section{Author's abstract}

In the past 20 years, around the world, there has been an explosion in the teaching of medical ethics. As the dust begins to settle, it would appear that such teaching is likely to have its most effective impact not during the undergraduate period but at the immediate postgraduate level and in continuing education. Whilst important contributions can be made by teachers of religion, philosophy and law, probably the essential wisdom, capable of standing a doctor in good stead throughout the developments of a lifetime's career, must largely come from those who have studied both medicine and ethics. It would be appropriate if the study of medical ethics were to lead to better international understanding among doctors.

In all the countries known to me, apparently no formal teaching in medical ethics took place until at least 1965. For example, an editorial in the fournal of the American Medical Association (1) in 1976 contained the comment that 'as an intellectual endeavour, medical ethics was virtually non-existent in American medical schools up to less than a decade before'; and Blomquist (2) in Sweden, writing in 1975 noted that nowhere in Europe today is there formal teaching in ethics for medical students'. Up to about twenty years ago, the traditional way of learning ethical concepts in medicine from the example of distinguished and admired clinical teachers had seemed adequate, and what formal instruction there was, was concerned more with matters of legality or medical etiquette.

During the last two decades there have arisen, as we all know, unprecedented problems for which learning by example has everywhere become inadequate. And everywhere the spotlight of publicity has been turned by the media onto the manner in which doctors take their many unavoidable decisions.

Needless to say, the spotlight has had its greatest wattage in the United States of America, generating heat as well as light, incubating and hotting up arguments for which few doctors in my generation

\section{Key words}

Teaching; medical ethics; bioethics; inter-faculty courses; medical humanities; ethicists; codes of ethics. were prepared. There is still a major distinction between the USA and ourselves in regard to decisionmaking, which essentially we continue to regard as ultimately a medical responsibility, whereas in America many other disciplines believe they have an equal right not only to an opinion, but also to a power of decision in matters of life and death.

In 1963 a committee of the Association of American Medical Colleges began to make plans for a Society of Health and Human Values, which came fully into existence in 1969. With funding from the National Endowment for the Humanities, the society supports an Institute of Human Values in Medicine - its director, Dr Edmund Pellegrino, has written a great deal on the 'humanising' of medicine, a sad tautological reflection on our profession - and the society publishes a Fournal of Medicine and Philosophy. By 1969, also, there had come into existence the Hastings Institute of Society, Ethics and Life Sciences (3) which organises conferences and publishes reports; and also the Kennedy Institute of Human Reproduction and Bioethics, which aims to encourage an academic approach and research. By 1973 it was possible to record a 'massive growth' of courses in the previous five years, many of which took the form of summer schools, with teachers drawn from law, religion and nursing, as well as medicine. Tensions were, however, even then developing as to how far those from nonscientific disciplines could contribute to discussion of highly complex medical problems, and a new breed of 'ethicists' not surprisingly began to make its appearance.

In 1974 , on the initiative of the Hastings Center, a national commission began a three-year study on the teaching of medical ethics in American medical schools (4). Out of 112 schools, 107 replied to a questionnaire; 97 claimed to give special instruction in medical ethics (the other ten schools excused themselves as new or still provisionally accredited) but of the 97 , only in six was the course in medical ethics mandatory; it was elective in 47; ethical issues were discussed in a variety of courses in 69; 56 arranged conferences or lectures; and, interestingly, 12 schools had created clerkships of one month's duration during which ethical problems arising in any part of the hospital would be intensively studied, with the aid of an ethicist. The commission 
noted that in a period of two years there had been a threefold increase in the provision of courses - trust American enthusiasm - and a 50 per cent increase in the number of teachers involved.

Among American developments in the 70s, illustrative of an intensification of academic involvement in medical ethics (3), I may mention a collaborative effort between the Kennedy Institute and Georgetown University, Washington DC, providing a $\mathrm{PhD}$ course in bioethics and the publication of a bibliographical record of new titles in bioethics; a joint programme between the Institute for the Medical Humanities in Galveston, the University of Texas at Austin and the Southern Methodist University; the institution of MA and $\mathrm{PhD}$ degrees in bioethics at the University of Tennessee; the introduction at Hershey Medical School, Pennsylvania, of 15 elective courses in medical ethics, two of which must be taken; a Harvard inter-faculty programme in medical ethics, involving the Divinity School, the School of Public Health, the Graduate School of Arts and Sciences and the Medical School; and from 1974 the foundation by the University of California, Los Angeles (UCLA) School of Medicine, its Aesculapian Society, the UCLA Committee on Public Lectures and the UCLA Medical Center, of a medical and social forum (5) providing a series of tightly organised videotapes to form the basis for small group discussions. And by 1979 the National Science Foundation had established EVIST (6), a programme of Ethics and Values in Science and Technology.

Despite, or because of, the multiplication of courses, Brody (7), writing in the $\mathcal{F} A M A$ in 1974 , was already bewailing a lack of definition of objectives and a failure to build in a process of evaluation of courses, without which students were regarding courses in ethics as unserious, irrelevant and avoidable. A course in Ohio (8), which began in 1979 , seemed to go to the other extreme: it has been described as a cognitivedevelopmental approach, based on psychological and educational theories and philosophical rationale, and is based on six stages of moral reasoning.

Recently the State of California has legislated for the compulsory inclusion of teaching of medical ethics in its medical schools (also human sexuality and recognition of child abuse); and before leaving the USA I should emphasise that there is an ongoing, widespread and passionate debate on the ethics of social policies in the provision of primary health care.

I have spent much of my short time on the American ethical scene; it is inexhaustible and overwhelming in its manifestations and certain to influence, if it is not already doing so, all other countries.

In Canada, it was noted in 1982 (9) that McGill had had formal undergraduate instruction in medical ethics 'for some time', based in a Department of Humanities and Social Studies in Medicine. And the University of Western Ontario (10), with a neighbouring Westminster College, had set up by 1978 'a center for research on ethics and the quality of life'.
Coming over to Europe, Maastricht University in the Netherlands (11), which in 1975 was a new, eighth $\vec{F}$. school of medicine in Holland, introduced a new curriculum based largely on problem-oriented $\rightleftharpoons$ teaching, in small groups and with a lot of student self- $\stackrel{\overline{\underline{S}}}{+}$ teaching, which includes periods of training with GPs을 and social workers, all aided by an ethicist, who $\frac{\bar{D}}{\bar{n}}$ remains available throughout clinical training. The $\frac{\bar{\rho}}{5}$ new curriculum called for professorships in medical $\stackrel{\oplus}{\varrho}$ psychology, medical sociology and medical ethics. ® Most other Dutch schools provided lectures and $\vec{\circ}$

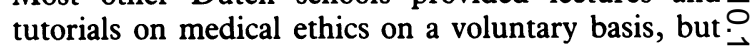
Nijmegen (12) went further, with monthly ethical $\vec{\omega}$ meetings and ethical discussions held regularly within ${ }^{\circ}$ six clinical departments.

West Germany, after World War II, was in a difficult, appropriately embarrassing situation in the $\overrightarrow{.}$ deep shadow of Nazism and the Nuremberg trials. $U p_{\dot{\sim}}$ to 1979 there was no systematic teaching of ethics at the $N$ undergraduate or graduate level, or in continuing 9 education (13). Even the old tradition of teaching by example was in difficulties because of the excessive number of students, insufficient opportunities for clinical experience, a lack of bedside oral $^{\Im}$ presentations, and a tightly packed six-year dictated $\vec{\oplus}$ curriculum. Freiburg University was perhaps the first. ${ }^{\text {. }}$ to show an ethical initiative, devising courses for medical students, student nurses and social workers.

In France (14), although about 98 per cent of the population are protected by insurance against the cost of illness, some 78 per cent of doctors (46 per cent of ${ }^{\mathbb{Q}}$ them GPs and 32 per cent specialists) practise privately $\overrightarrow{\vec{P}}$ and gain their incomes from fees. The legal and socialo 3 security background is complicated and this is reflected in some schools by the elaborate coursesơ. provided. According to Dr J Autin, Secretary-General, in Paris, of the Conférence Internationale des Ordres, the European Assembly of the medical regulatingo bodies within the European Economic Community, a? single course-package may include forensic medicine,, regulations of relations between doctors and other health professionals, human rights, consent too treatment, attitudes to torture, dangers to the public from alcoholism, abuse of drugs, commitment of the mentally ill, prevention of practice by the sick doctor, responsibilities of the doctor in a court of laws organisation of social security systems, accuracy and validity of certification, duties in case of death $N_{\omega}^{N}$ responsibilities in regard to examinations beforę marriage, contraception, abortion and crimes of sexuadb violence; and considerable instruction in health economics. The Ordre National - the equivalent of rather more than the registration responsibilities of the GMC - is active in producing video films giving? examples of ethical dilemmas in practice; and the French, as many of you know, have made $\overrightarrow{\mathbb{D}}$ praiseworthy attempt to impose a common ethicab outlook on the rest of Western Europe, buh unfortunately without due regard to the religious, lega and social backgrounds which still distinguish ous. separate countries. 
Medical ethics in Italy are usually taught as part of a course on legal medicine, according to information from Dr Rino Reggio, an officer of the Federazione Nazionale Degli Ordini Dei Medici, the equivalent in Italy of the British Medical Association. Since October 1983 the National Federation of Medical Orders has urged the provincial orders to set up courses of postgraduate continuing education about medical ethics and health legislation. The courses, which are already proving highly successful, include such topics as professional secrecy, obligation to co-operate with health authorities and the police, confidentiality of medical documentation, interruption of pregnancy, euthanasia, and experimentation on man.

Yugoslavia (15) introduced into its penal code in 1963 a Code of Ethics for Medical Workers, not only for doctors but also for all paramedicals. Undergraduates receive some thirty hours, and postgraduates some thirty to forty hours of instruction, in which forensic medicine includes coverage of medical ethics.

In a somewhat similar way, according to Edward Shotter, Director of the Institute of Medical Ethics President Ceaucescu in Romania, when asked about medical ethics, put it simply and without argument: 'A doctor shall have the same ethics as the worker'.

In 1975, at a conference in Bulgaria, the Russians poured scorn on the barbarity of the British when I was unable to produce evidence of the formal teaching 0 ethics in our medical schools, but retreated into silence when I told them of student initiative and energy in the busy activities of the London Medical Group and the (then) Society for the Study of Medical Ethics.

Last, but very far from least, the situation in Scandinavia: according to Blomquist (2), the first academic teacher in medical ethics was appointed in 1975 , but his teaching and research were to be carried out beyond his full-time duties as a clinical psychiatrist and lecturer in psychiatry. Voluntary courses for medical students were begun in 1975, but it was soon evident, as Blomquist says, that 'it is easier for a medical doctor to learn ethics than for a moral philosopher to learn medicine'. The Swedish Society of Medical Sciences set up a Delegation for Medical Ethics which included a representative from medicine, surgery, paediatrics, psychiatry and clinical pharmacology, four lay members and trade union and legal representatives.

Denmark shows perhaps the greatest activity, according to Dr Povl Riis, Physician-in-Chief of the Medical Gastroenterological Department in the University Hospital, Copenhagen, possibly because they have experimented so freely in social behaviour. Nevertheless, at the undergraduate level, in the threc medical schools there is no formal ethical teaching There are two small textbooks for undergraduates.
However, at the postgraduate level there are no less than forty to fifty intensive courses in which ethical considerations are much to the fore in discussion of medical and scientific methodology. A course usually lasts six days, one day being reserved for ethics and research. The Danish Medical Association also includes ethics in many courses for GPs. The Danes even export the teaching of medical ethics - under the direction of Dr Riis, the courses have been extended to Greenland, Iceland, the Faroes, Sweden, The Netherlands, Yugoslavia, even the UK - and in April 1984 courses were held in China.

So perhaps an international outlook, which in our Western medicine is so often lacking, may at last be opened up on a global basis, appropriately through the teaching of medical ethics.

\section{References}

(1) Anonymous. Medical ethics, education and the physician's image. [editorial]. Fournal of the American Medical Association 1976; 235: 1043.

(2) Blomquist C. The teaching of medical ethics in Sweden. Journal of medical ethics 1975; 1: 96-98.

(3) Veatch R M, Fenner D. The teaching of medical ethics in the United States of America. Fournal of medical ethics 1975; 1: 99-101.

(4) Veatch R M; Sollito S. Medical ethics teaching. Report of a national medical school survey. Fournal of the American Medical Association 1976; 235: 1030-33.

(5) Anonymous. Medicine and society forum, university of California, Los Angeles. News and notes. Fournal of medical ethics 1975; 1: 159.

(6) Anonymous. Changing values in medicine. News and notes. Fournal of medical ethics 1979; 5: 153.

(7) Brody H. Teaching of medical ethics. Fournal of the American Medical Association 1974; 229: 177-179.

(8) Goldman S A, Arbuthnot J. Teaching medical ethics: the cognitive-developmental approah. Fournal of medical ethics 1979; 5: 170-181.

(9) Lella J. Letter: Teaching of medical ethics. Fournal of medical ethics 1982; 8: 111 .

(10) Anonymous. [editorial]. Ethical codes and professional conduct. Fournal of medical ethics 1978; 4: 105.

(11) Sporken P. The teaching of medical ethics in Maastricht. Fournal of medical ethics 1975; 1: 181-183.

(12) Wachter M A M de. Teaching medical ethics: University of Nijmegen, The Netherlands. Fournal of medical ethics 1978; 4: 84-88.

(13) Seidler E. The teaching of medical ethics in the Federal Republic of Germany. Fournal of medical ethics 1979; 5: 76-79.

(14) Regnier F, Rouzioux J-M. Certain aspects of medical ethics in France. Fournal of medical ethics 1983; 9: 170 174.

(15) Milciuski J, Stražišćar S. Teaching medical ethics: Ljubljana School of Medicine, Yugoslavia. Fournal of medical ethics 1980; 6: 145-148. 